\title{
IMPACT OF SMALL AND MEDIUM-SIZED TOURISM FIRMS ON EMPLOYMENT IN KAZAKHSTAN
}

\author{
Aliya AKTYMBAYEVA* \\ Al-Farabi Kazakh National University, Faculty of Geography and Environmental Sciences, \\ 050040, Al-Farabi ave., 71, Almaty, Kazakhstan, e-mail: Aktymbayeva@kaznu.kz
}

Zhanna ASSIPOVA

Al-Farabi Kazakh National University, Faculty of Geography and Environmental Sciences, 050040, Al-Farabi ave., 71, Almaty, Kazakhstan, e-mail: Assipova@kaznu.kz

Aitolkyn MOLDAGALIYEVA

Al-Farabi Kazakh National University, Faculty of Geography and Environmental Sciences, 050040, Al-Farabi ave., 71, Almaty, Kazakhstan, e-mail: Sakypbek@kaznu.kz

\section{Yeldar NURULY}

Al-Farabi Kazakh National University, Faculty of Geography and Environmental Sciences, 050040, Al-Farabi ave., 71, Almaty, Kazakhstan, e-mail: Nuruly@kaznu.kz

\section{Asima KOSHIM}

Al-Farabi Kazakh National University, Faculty of Geography and Environmental Sciences, 050040, Al-Farabi ave., 71, Almaty, Kazakhstan, e-mail: Koshim@kaznu.kz

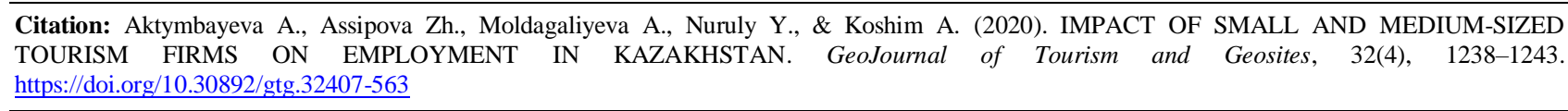

\begin{abstract}
Nowadays, small and medium-sized tourism firms play a key role in the development of the national economy of Kazakhstan. In 2019 , there were over 7000 small and medium-sized tourism firms in Kazakhstan. The tourism firms have many contributions to make labor-intensive and more often self-proprietary, comparatively improved levels of efficiency and better income distribution, has a strong socio-economic imperative for the country, and disseminates broadly the benefits of economic growth. However, there is a little information available on the impact of tourism firms on employment in Kazakhstan. The objective of this manuscript is to fill this information gap by inve stigating the impact of tourism firms on employment by applying regression analysis. The results of the regression analysis revealed that there is a positive relationship between tourism firms and unemployment reduction. This manuscript may be beneficial for practitioners and academicians. Examining the impact of tourism firms on employment tends to raise or provide some use ful insights into some theoretical issues on one hand. On the other hand, it raises some practical implications for policy makers in the government.
\end{abstract}

Key words: tourism firms, employment, regression analysis, Kazakhstan

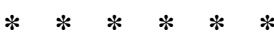

\section{INTRODUCTION}

Nowadays, it has become obvious that the development of a competitive socially oriented market economy is impossible without building a flexible labor market. The analysis of the impact of tourism firms on the development of the labor market and empl oyment is becoming especially relevant, which formulates a set of effective measures aimed at increasing employment and developing the economy as a whole (Davis et al., 1996; Foelster, 2000; Carree et al., 2002; Acs and Armington, 2004; Oosterbeek et al., 2010; Doran et al., 2016). Quantitative and qualitative indicators reflecting the state of the labor market are simultaneously indicators of the effectiveness of using the investment, organizational and financial potentials of the labor market, as well as the national e conomy as a whole (Baumol, 1993; Rocha, 2004; Mueller, 2007; Cumming et al., 2014; Al-Haddad, et al., 2019). They characterize the state and direction of development of an entrepreneurial society, whose participants, along with the functions of producing goods and services, combining factors of production, stimulating aggregate demand and introducing the achievements of scientific and technological progress, perform a social function consisting in creating jobs, which determines the quality and the standard of living of the population, the state of human capital (Lepoutre and Haener, 2006; Taiwo et al., 2012; Memili et al., 2015; Maksimov et al., 2017).

This is an objective prerequisite for the formation and implementation of labor potential, the rate and type of economic growth depend on the volume and quality (Audretsch and Thurik, 2001). Entrepreneurial structures on the labor market and employment is determined by many factors, among which are: the type of economic activity performed, the legal form, the level of concentration and centralization of production, etc. (Malesios et al., 2018). In this regard, it seems necessary to identify business entities in as independent participants in the labor market, which will determine the characteristics of labor resources, changing under the influence of entrepreneurial activity tee (Aliyeva et al., 2020). Interest in such a study is growing due to the deterioration of the macroeconomic situation in the context of aggravating geopolitical risks, which inevitably affects the state of the labor potential of the national economy as a whole and of individual territorial entities (Audretsch and Keilbach, 2008; Lonial and Carter, 2015).

Historically, tourism firms have not played an important role in Kazakhstan due to specific resource-based economy (Koshim et al., 2018; Koshim et al., 2019). Resource sector in particular energy is by far the most important for Kazakhstan's economy (Movke bayeva et al., 2020). It accounts for one quarter of its total GDP and just under one third of its total industrial production, and contributes about

\footnotetext{
* Corresponding author
} 
half the income to the annual budget (Karatayev and Hall, 2020). Energy exports, which account for $60 \%$ of total national exports, have been the crucial factor that explains the impressive annual rise of 7-10\% of Kazakhstan's GDP for the years $2010-2019$ (Karatayev et al., 2016). To reduce reliance on resource export, government aims to develop sustainable knowledge-based economy (Karatayev and Hall, 2017) with dynamic activities in small and medium entrepreneurship sector.

The effective development of entrepreneurial activity depends on the influence of external and internal environment (Lerner and Haber, 2001; Nga and Shamuganathan, 2010; Noguera et al., 2013; Bruton et al., 2013; Aparicio et al.2016).

An analysis of external (international, political, economic, legal, environmental, technological, social, market) and internal (consumers, suppliers, competitors) factors is necessary for the development and implementation of a balanced state regulatory policy, which should meet the interests of small and medium-sized enterprises and promote growth degrees of economic freedom of business (Singh et al., 2012). According to the National Statistics Agency in 2019, 1.2 million small and medium-sized enterprises were registered in Kazakhstan (NSA, 2019). Small and medium-sized enterprises employ 21\% of the total number of people active in the economy and account for about $24 \%$ of the total turnover of products and services produced by enterprises in the country.

Of these, $57.6 \%$ of small and medium-sized enterprises are individual entrepreneurs, $28.1 \%$ are joint entities, $22.4 \%$ of them are microenterprises, $8.6 \%$ are small enterprises and $0.9 \%$ are medium-sized enterprises (Saiymova et al., 2018). The main activities of small and medium enterprises are trade (more than 36.7\%) and the provision of services (28.6\%). In 2019, over 7000 tourism firms in Kazakhstan were registered as small and medium enterprises. In addition, in Kazakhstan, there is a high level of employment and low unemployment (NSA, 2020). The employment rate is $75.1 \%$ and the overall unemployment rate is $8.5 \%$ (Saiymova et al., 2020). In this regard, there is growing interest in modeling the tourism firms' impact on employment.

\section{METHODOLOGY}

Regression analysis, as a combination of mathematical methods for detecting the correlation between random variables or attributes, allows a comparison of a number of indicators in the field of employment in tourism firms and further develop a model of the measured data and study their properties (Menard, 2000; Peng et al., 2002; Tonidandel \& LeBreton, 2011). Data sets for regression analysis were obtained from National Statistic Agency for 2011-2019 period (NSA, 2020). This Agency is national provider of credible, relevant, accurate, and timely statistics that are essential for policy makers, individuals, households, businesses, academic institutions, and other organizations to make informed decisions. The data on socioeconomic and entrepreneurial trends in Kazakhstan is available on https://stat.gov.kz/.

The indicator "Employment dynamics" was selected as the resulting indicator. The dynamics of the growth rate of employees in tourism firms for the period 2011-2019 has a general growth trend (Table 1). In many respects, the positive dynamics of this indicator is due to the development of the financial and credit support system for tourism firms and the solution of the problem of access to financial resources and the active participation of local financial institutions in lending to tourism firms.

Table 1. Employment dynamics, in \% (Source: NSA, 2020)

\begin{tabular}{|l|l|l|l|l|l|l|l|l|l|}
\hline & 2011 & 2012 & 2013 & 2014 & 2015 & 2016 & 2017 & 2018 & 2019 \\
\hline Indicator growth rate & 101.1 & 102.5 & 102.6 & 97.3 & 104.3 & 103.6 & 100.4 & 103.9 & 103.5 \\
\hline
\end{tabular}

The following indicators were selected as factors influencing the rate of growth of employment: $\mathrm{X}_{1}$ - share of small and medium-sized tourism firms; $\mathrm{X}_{2}$ - share of economic active population; $\mathrm{X}_{3}$ - share of employed persons; $\mathrm{X}_{4}$ - share of employed persons with higher education; $X_{5}$ - share of unemployed persons; $X_{6}$ - share of persons outside the labour force; $X_{7}$ - the average monthly wage of the population; $\mathrm{X}_{8}$ - real disposable income of the population; $\mathrm{X}_{9}$ - inflation rate.

The first factors selected for the development of the economic and mathematical model is the dynamics of the growth rate of the number of tourism firms for the period 2011-2019 in \% to the previous year (Table 2). This indicator is a kind of barometer of the economy, as a result, has very unstable dynamics: during periods of economic growth - the number of tourism firms increases, during moments of economic recession quantitative growth of tourism firms does not occur.

Table 2. The growth of tourism firms, in \% (Source: NSA, 2020)

\begin{tabular}{|l|c|c|c|c|c|c|c|c|c|}
\hline & 2011 & 2012 & 2013 & 2014 & 2015 & 2016 & 2017 & 2018 & 2019 \\
\hline Indicator growth rate & 106.7 & 111.7 & 113.0 & 112.6 & 103.8 & 99.7 & 96.0 & 101.2 & 106.7 \\
\hline
\end{tabular}

Analyzing the following indicator "The growth of the economic active population" in \% to the previous year (Table 3 ), we note that the largest increase in the economically active population in Kazakhstan was recorded in 2012.

Table 3. The growth of economic active population, in \% (Source: NSA, 2020)

\begin{tabular}{|l|r|r|r|r|r|r|r|r|r|}
\hline & 2011 & 2012 & 2013 & 2014 & 2015 & 2016 & 2017 & 2018 & 2019 \\
\hline Indicator growth rate & 103.6 & 105.8 & 101.5 & 99.8 & 101.8 & 101.9 & 102.6 & 97.7 & 97.2 \\
\hline
\end{tabular}

As the next factor selected for the correlation and regression analysis, the indicator "The growth of the employed persons" in $\%$ to the previous year was selected (Table 4). The minimum value is noted in $2014-93.5 \%$, after which the general trend of employment of the population until the end of the period becomes positive.

Table 4. The growth of the employed persons, in \% (Source: NSA, 2020)

\begin{tabular}{|l|l|l|c|c|c|c|c|c|c|}
\hline & 2011 & 2012 & 2013 & 2014 & 2015 & 2016 & 2017 & 2018 & 2019 \\
\hline Indicator growth rate & 101.0 & 100.7 & 97.3 & 93.5 & 98.8 & 100.2 & 103.3 & 98.2 & 100.2 \\
\hline
\end{tabular}

In direct proportion to the economic situation are not only indicators of changes in employment and unemployment, but also the quality of the workforce, determined by the level of education. Therefore, the next factor was selected "The growth of employed persons with higher education" in \% to the previous year (Table 5). Higher education is very important in the current economic environment, as it enables potential employees to choose from a wider range of vacancies, while people with secondary, specialized secondary or vocational education are very limited in their choice in employment. The important issue remains the quality of education, the level of training of specialists. The overall dynamics of this indicator is negative, which negatively affects the activities of enterprises. 
Table 5. The growth of employed persons with higher education, in \% (Source: NSA, 2020)

\begin{tabular}{|l|l|r|r|r|r|r|r|r|r|}
\hline & 2011 & 2012 & 2013 & 2014 & 2015 & 2016 & 2017 & 2018 & 2019 \\
\hline Indicator growth rate & 111.5 & 99.7 & 99.5 & 105.3 & 96.1 & 95.0 & 99.7 & 92.7 & 94.0 \\
\hline
\end{tabular}

The next indicator selected is "The growth of unemployed" in \% to the previous year (Table 6). The minimum value noted in 2017 is $65.6 \%$. The maximum growth rate of the number of unemployed in the study period was recorded in 2014 , and then it amounted to $140.4 \%$.

Table 6. The growth of unemployed persons, in \% (Source: NSA, 2020)

\begin{tabular}{|l|l|l|l|l|l|l|l|l|l|}
\hline & 2011 & 2012 & 2013 & 2014 & 2015 & 2016 & 2017 & 2018 & 2019 \\
\hline Indicator growth rate & 78.1 & 98.1 & 98.3 & 140.4 & 92.1 & 85.5 & 65.6 & 90.6 & 66.2 \\
\hline
\end{tabular}

One of the important indicators for analysis impact of small and medium-sized tourism firms on employment is the share of persons outside the labour force (Table 7). The inactivity rate is the proportion of the working-age population that is not in the labour force. A subgroup of persons outside the labour force comprises those known as discouraged jobseekers, defined as persons not in the labour force, who are available for work but no longer looking for work due to specific labour market-related reasons, such as the belief that there are no jobs available.

Table 7. The growth of persons outside the labour force, in \% (Source: NSA, 2020)

\begin{tabular}{|l|l|c|c|c|c|c|c|c|l|}
\hline & 2011 & 2012 & 2013 & 2014 & 2015 & 2016 & 2017 & 2018 & 2019 \\
\hline Indicator growth rate & 83.6 & 101.6 & 98.8 & 102.9 & 97.6 & 90.1 & 71.1 & 96.1 & 73.8 \\
\hline
\end{tabular}

The next factor for the development of the model was selected the factor "The growth of the average monthly wage of the population" in $\%$ to the previous year (Table 8 ). The average monthly wage affects the level of employment, not only as a motivating indicator, but also as an argument for the development of tourism firms in certain industries. The dynamics of this indicator does not have a pronounced growth or decline trend. For the growth rates of the average monthly wage during the study period, transitions are observed: the maximum value was noted in 2012 - the growth rate was 122\%, and the minimum - in 2014, when the growth rate was $99.4 \%$.

Table 8 . The growth of the average monthly wage of the population, in \% (Source: NSA, 2020)

\begin{tabular}{|l|l|l|l|r|r|r|r|r|c|}
\hline & 2011 & 2012 & 2013 & 2014 & 2015 & 2016 & 2017 & 2018 & 2019 \\
\hline Indicator growth rate & 121.6 & 122.0 & 121.1 & 99.4 & 108.3 & 110.8 & 109.6 & 110.7 & 106.0 \\
\hline
\end{tabular}

Another indicator for conducting a multivariate analysis was selected "The growth of real disposable income of population" (Table 9). In contrast to the average monthly wage, the trends in the growth rates of real disposable income of citizens have a general tendency to decrease. The maximum value was recorded in 2012, when the growth rate of the indicator was $111.2 \%$. The minimum value was noted in 2014 - the growth rate of the indicator was $97 \%$. The influence of real disposable income of citizens on the level of employment in tourism firms is determined by means of additional income, part-time employment, and other equally important criteria.

Table 9. The growth of real disposable income of population, in \% (Source: NSA, 2020)

\begin{tabular}{|l|l|l|l|r|r|r|l|l|l|}
\hline & 2011 & 2012 & 2013 & 2014 & 2015 & 2016 & 2017 & 2018 & 2019 \\
\hline Indicator growth rate & 109.0 & 111.2 & 109.4 & 97.0 & 101.7 & 104.0 & 104.1 & 104.1 & 103.6 \\
\hline
\end{tabular}

The last indicator of the economic-mathematical model was chosen as "The growth of inflation" in \% to the previous year (Table 10). Analyzing the data in the table, we can conclude that in crisis periods (2013 and 2019), the maximum value of this indicator is noted - 9.8 and $10.7 \%$, respectively. The growth rate of inflation reflects the growth rate of prices and affects the state of the economy of economic entities, the level of development of the regions and the country as a whole. The increase in inflation negatively affects the financial and economic situation of tourism firms; as a result, the unstable situation entails a decrease in the level of employment in this sector of the economy.

Table 10. The growth of inflation, in \% (Source: NSA, 2020)

\begin{tabular}{|c|c|c|c|c|c|c|c|c|c|}
\hline & 2011 & 2012 & 2013 & 2014 & 2015 & 2016 & 2017 & 2018 & 2019 \\
\hline Indicator growth rate & 6.7 & 6.0 & 9.8 & 10.7 & 7.1 & 7.6 & 6.5 & 7.4 & 9.8 \\
\hline
\end{tabular}

To conduct a correlation regression analysis, it is necessary to form a summary table of indicators that affect the dynamics of the number of employees in tourism firms. Table 11 and Figure 1 serves as input to the development of a pair correlation matrix.

Table 11. A summary of indicators (Source: compiled by the authors)

\begin{tabular}{|c|c|c|c|c|c|c|c|c|c|}
\hline Indicators & 2011 & 2012 & 2013 & 2014 & 2015 & 2016 & 2017 & 2018 & 2019 \\
\hline $\mathrm{Y}$ & 101.1 & 102.5 & 102.6 & 97.3 & 104.3 & 102.6 & 100.4 & 103.6 & 102.5 \\
\hline $\mathrm{X}_{1}$ & 106.7 & 111.7 & 113.0 & 112.6 & 103.8 & 99.7 & 96.0 & 101.2 & 106.7 \\
\hline $\mathrm{X}_{2}$ & 103.6 & 104.8 & 101.5 & 99.8 & 101.8 & 101.9 & 102.6 & 97.7 & 97.2 \\
\hline $\mathrm{X}_{3}$ & 101.0 & 100.7 & 97.3 & 93.5 & 98.8 & 100.2 & 103.3 & 98.2 & 100.2 \\
\hline $\mathrm{X}_{4}$ & 111.5 & 99.7 & 99.5 & 105.3 & 96.1 & 95.0 & 99.7 & 92.7 & 94.0 \\
\hline $\mathrm{X}_{5}$ & 78.1 & 98.1 & 98.3 & 140.4 & 92.1 & 85.5 & 65.6 & 90.6 & 66.2 \\
\hline $\mathrm{X}_{6}$ & 83.6 & 101.6 & 98.8 & 102.9 & 97.6 & 90.1 & 71.1 & 96.1 & 73.8 \\
\hline $\mathrm{X}_{7}$ & 121.6 & 122.0 & 121.1 & 99.4 & 108.3 & 110.8 & 109.6 & 110.7 & 106.0 \\
\hline $\mathrm{X}_{8}$ & 109.0 & 111.2 & 109.4 & 97.0 & 101.7 & 104.0 & 104.1 & 104.1 & 103.6 \\
\hline $\mathrm{X}_{9}$ & 6.7 & 6.0 & 9.8 & 10.7 & 7.1 & 7.6 & 6.5 & 7.4 & 9.8 \\
\hline
\end{tabular}

\section{RESULTS AND DISCUSSION}

Using a correlation regression analysis, we obtain a matrix of pair correlation coefficients (Table 12). Factors such as: $\mathrm{X}_{3}$ - number of employees; $\mathrm{X}_{6}$ - the average monthly wage of the population; $\mathrm{X}_{7}$ - real disposable income of the population; $\mathrm{X}_{8}$ - the inflation rate does 
not satisfy the conditions of the study, therefore it is discarded. An analysis of the matrix of pair correlation coefficients showed the presence of a relationship of factors and the resulting indicator, thereby determining the influence of the criteria on the change in the number of employees in tourism firms. The second step in building a model is conducting a regression analysis. Regression is necessary to analyze the effect of factors $\mathrm{X}$ on the resulting indicator $\mathrm{Y}$ by deriving some functional dependence, called the regression equation or correlation regression model (Table 13). As a result of the regression analysis, the value of the "R-squared" indicator, which is the coefficient of determination, amounted to 0.957275 . The coefficient of determination, the factors included in the model, more than $70 \%$ determine the impact on the change in the number of employees in tourism firms. As a result of the regression, the coefficients necessary for compiling the regression equation were also obtained (Table 14). Based on the results obtained, the regression equation takes the form: $\mathrm{Y}=110.5337+0.053807 \mathrm{X}_{1}+0.114424 \mathrm{X}_{2}-0.18223 \mathrm{X}_{4}-0.09027 \mathrm{X}_{5}$. The obtained equation meets the goal of correlation and regression analysis and is a linear multivariate model of the dependence of the number of people employed in tourism firms on four main factors, each of which affects the change in the number of employed people in the tourism firms.

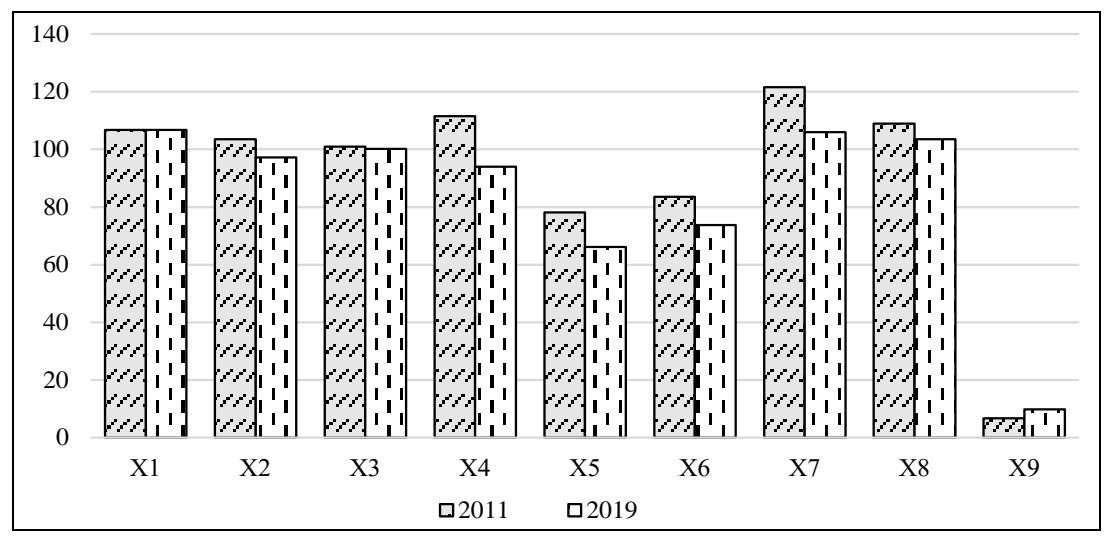

Figure 1. A summary of indicators (Source: compiled by the authors)

The economic sense of developing a correlation and regression model is as follows: an increase in the number of tourism firms by $1 \%$ will contribute to an increase in the number of employees in tourism firms by $0.05 \%$; a $1 \%$ reduction in the number of working citizens with higher education will contribute to an increase in the number of people employed in tourism firms by $0.18 \%$; a decrease in the number of unemployed by $1 \%$ will contribute to an increase in the number of people employed in tourism firms by $0.09 \%$ (Table 15 ). As a result of calculations and economic analysis, it was found that the greatest impact on the change in the number of people employed in tourism firms is exerted by the number of tourism firms, the number of economically active population, the number of working citizens with higher education and the number of unemployed.

Table 12. A matrix of pair correlation coefficients (Source: compiled by the authors)

\begin{tabular}{|c|c|c|c|c|c|c|c|c|c|c|}
\hline & $\mathrm{Y}$ & $\mathrm{X}_{1}$ & $\mathrm{X}_{2}$ & $\mathrm{X}_{3}$ & $\mathrm{X}_{4}$ & $\mathrm{X}_{5}$ & $\mathrm{X}_{6}$ & $\mathrm{X}_{7}$ & $\mathrm{X}_{8}$ & $\mathrm{X}_{9}$ \\
\hline $\mathrm{Y}$ & 1 & & & & & & & & & \\
\hline $\mathrm{X}_{1}$ & 0.85 & 1 & & & & & & & & \\
\hline $\mathrm{X}_{2}$ & 0.88 & 0.99 & 1 & & & & & & & \\
\hline $\mathrm{X}_{3}$ & 0.68 & 0.86 & 0.86 & 1 & & & & & & \\
\hline $\mathrm{X}_{4}$ & 0.89 & 0.99 & 0.99 & 0.86 & 1 & & & & & \\
\hline $\mathrm{X}_{5}$ & 0.87 & 0.99 & 0.99 & 0.82 & 1.00 & 1 & & & & \\
\hline $\mathrm{X}_{6}$ & 0.84 & 0.86 & 0.87 & 0.89 & 0.96 & 0.99 & 1 & & & \\
\hline $\mathrm{X}_{7}$ & 0.83 & 0.85 & 0.95 & 0.94 & 0.70 & 0.96 & 0.98 & 1 & & \\
\hline $\mathrm{X}_{8}$ & 0.81 & 0.82 & 0.99 & 0.98 & 0.85 & 0.99 & 0.99 & 0.96 & 1 & \\
\hline $\mathrm{X}_{9}$ & 0.85 & 0.87 & 0.94 & 0.94 & 0.69 & 0.96 & 0.98 & 0.99 & 0.96 & 1 \\
\hline
\end{tabular}

Table 13. The indicators remaining after the correlation analysis (Source: compiled by the authors)

\begin{tabular}{|c|c|c|c|c|}
\hline $\mathrm{Y}$ & $\mathrm{X}_{1}$ & $\mathrm{X}_{2}$ & $\mathrm{X}_{4}$ & $\mathrm{X}_{5}$ \\
\hline 103.3 & 171 & 101.8 & 113.7 & 80.3 \\
\hline 100.7 & 108.9 & 102.6 & 101.9 & 100.3 \\
\hline 100.8 & 113.9 & 99.3 & 101.5 & 100.5 \\
\hline 95.1 & 109.8 & 97.6 & 107.5 & 142.6 \\
\hline 102.1 & 111.4 & 99.6 & 98.3 & 94.1 \\
\hline 100.8 & 105.6 & 99.7 & 97.2 & 87.5 \\
\hline 102.6 & 97.5 & 99.8 & 100.7 & 67.8 \\
\hline 101.4 & 98 & 99.9 & 94.9 & 92.8 \\
\hline 104.3 & 103 & 99.4 & 96.2 & 68.4 \\
\hline
\end{tabular}

Table 14. Regression statistics

\begin{tabular}{|c|c|}
\hline Multiple R & 0.978404 \\
\hline R- squared & 0.957275 \\
\hline Normalized R- squared & 0.91455 \\
\hline Standard Error & 0.763673 \\
\hline Observation & 9 \\
\hline
\end{tabular}

Table 15. Input data for regression equation

\begin{tabular}{|c|c|}
\hline $\mathrm{Y}$ & 110.5337 \\
\hline $\mathrm{X}_{1}$ & 0.053807 \\
\hline $\mathrm{X}_{2}$ & 0.114424 \\
\hline $\mathrm{X}_{4}$ & -0.18223 \\
\hline $\mathrm{X}_{5}$ & -0.09027 \\
\hline
\end{tabular}

The resulting model can be used to predict changes in the average number of employees at certain factor values. The values of such indicators as the number of tourism firms, the number of economically active population, the number of working citizens with higher 
education, the number of unemployed for the period 2011-2019 were used as initial data for the development of forecast values for 20202022 (Table 16, Figure 2). Thus, in the process of developing forecasted indicator values, all factors have a positive dynamic, with the exception of the dynamics rate of the economically active population.

Table 16. Forecast of indicator values (Source: compiled by the authors)

\begin{tabular}{|c|c|c|}
\hline Indicators & 2020 & 2022 \\
\hline $\mathrm{Y}$ & 102.5 & 104.2 \\
\hline $\mathrm{X}_{1}$ & 89.2 & 89.8 \\
\hline $\mathrm{X}_{2}$ & 98.8 & 98.6 \\
\hline $\mathrm{X}_{4}$ & 93.1 & 91.8 \\
\hline $\mathrm{X}_{5}$ & 75.6 & 63.6 \\
\hline
\end{tabular}

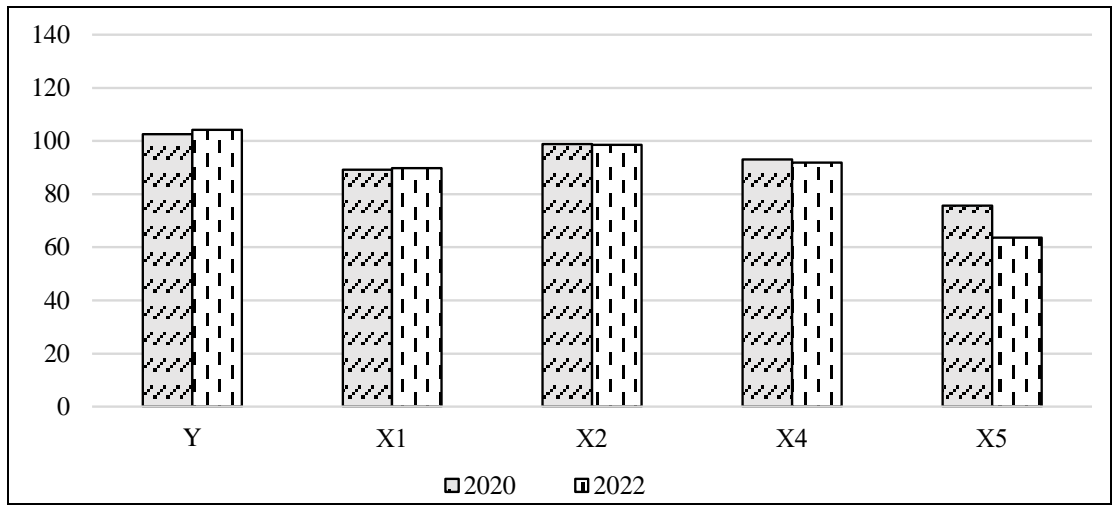

Figure 2. Forecast of indicator values (Source: compiled by the authors)

\section{CONCLUSION}

Small and medium-sized tourism firms provide a relatively higher growth rate of the number of employees. The analysis allows, thus, showing some features of the functioning and development of tourism firms in the modern market system, to identify its role in solving employment problems. It has been established that tourism firms are in demand and successful where the demand for products is often changing in nature or personified. These areas include the service sector (in this area, the total share of employees in tourism firms has traditionally increased), art, craftsmanship, etc. The tourism firms can actively create jobs for socially vulnerable categories of the population, contributes to the development of self-employment.

However, one should also point out the ambiguous impact of the development of tourism firms on employment processes, since, on the one hand, tourism firms, expanding, attracts more and more free labor, but at the same time fierce competition both within the tourism system and between tourism firms and big business, leads to the ruin of part of small enterprises and the loss of jobs. Hence, there is a need to create such conditions for the functioning of the tourism system under which employment growth would be stable.

\section{ACKNOWLEDGMENT}

This manuscript was written under grant from Kazakhstan Ministry of Education and Science No 20048005 "Impact of small and medium-sized tourism firms on employment in Kazakhstan" coordinated by Dr Aliya Aktymbayeva (Al-Farabi Kazakh National University).

\section{REFERENCES}

Acs, Z., \& Armington, C. (2004). Employment growth and entrepreneurial activity in cities. Regional studies, 38(8), 911-927. https://doi.org/10. $1080 / 0034340042000280938$

Al-Haddad, L., Sial, M.S., Ali, I., Alam, R., Khuong, N.V., \& Thuy, T.H. (2019). The Role of Small and Medium Enterprises (SMEs) in Employment Generation and Economic Growth: A Study of Marble Industry in Emerging Economy. International Journal of Financial Research, 10(6). https://doi.org/10.5430/ijfr.v10n6p174

Aliyeva Z., Sakypbek, M., Aktymbayeva, A., Assipova, Z., \& Saidullayev, S. (2020). Assessment of recreation carrying capacity of Ile-Alatau national park in Kazakhstan. GeoJournal of Tourism and Geosites, 29 (2), 460-471. https://doi.org/10.30892/gtg.29207-482

Aparicio, S., Urbano, D., \& Audretsch, D. (2016). Institutional factors, opportunity entrepreneurship and economic growth: Panel data evidence. Technological forecasting and social change, 102, 45-61. https://doi.org/10.1016/j.techfore.2015.04.006

Audretsch, D.B., \& Keilbach, M. (2008). Resolving the knowledge paradox: Knowledge-spillover entrepreneurship and economic growth. Research Policy, 37(10), 1697-1705. https://doi.org/10.1016/j.respol.2008.08.008

Audretsch, D.B., \& Thurik, A.R. (2001). What's new about the new economy? Sources of growth in the managed and entrepreneurial economies. Industrial and corporate change, 10(1), 267-315. https://doi.org/10.1093/icc/10.1.267

Baumol, W.J. (1993). Formal entrepreneurship theory in economics: Existence and bounds. Journal of business venturing, 8(3), 197-210. https://doi.org/10.1016/0883-9026(93)90027-3

Bruton, G.D., Filatotchev, I., Si, S., \& Wright, M. (2013). Entrepreneurship and strategy in emerging economies. Strategic Entrepreneurship Journal, 7(3), 169-180. https://doi.org/10.1002/sej.1159

Carree, M., Van Stel, A., Thurik, R., \& Wennekers, S. (2002). Economic development and business ownership: an analysis using data of 23 OECD countries in the period 1976-1996. Small business economics, 19(3), 271-290. https://doi.org/10.1023/a:1019604426387

Cumming, D., Johan, S., \& Zhang, M. (2014). The economic impact of entrepreneurship: Comparing international datasets. Corporate Governance: An International Review, 22(2), 162-178. https://doi.org/10.1111/corg.12058

Davis, S.J., Haltiwanger, J., \& Schuh, S. (1996). Small business and job creation: Dissecting the myth and reassessing the facts. Small business economics, 8(4), 297-315. https://doi.org/10.1007/bf00393278

Doran, J., McCarthy, N., \& O'Connor, M. (2016). Entrepreneurship and employment growth across European regions. Regional Studies, Regional Science, 3(1), 121-128. https://doi.org/10.1080/21681376.2015.1135406

Foelster, S. (2000). Do entrepreneurs create jobs?. Small business economics, 14(2), 137-148. https://doi.org/10.1023/a:1008141516160 
Karatayev, M., \& Hall, S. (2017). Integration of wind and solar power in Kazakhstan: Incentives and barriers. Sustainable Energy in Kazakhstan, (pp. 65-89). Routledge. ttps://doi.org/10.4324/9781315267302-5

Karatayev, M., \& Hall, S. (2020). Establishing and comparing energy security trends in resource-rich exporting nations (Russia and the Caspian Sea region). Resources Policy, 68, 101746. https://doi.org/10.1016/j.resourpol.2020.101746

Karatayev, M., Hall, S., Kalyuzhnova, Y., \& Clarke, M.L. (2016). Renewable energy technology uptake in Kazakhstan: Policy drivers and barriers in a transitional economy. Renewable and Sustainable Energy Reviews, 66, 120-136. https://doi.org/10.1016/j.rser.2016.07.057

Koshim, A.G., Sergeyeva, A.M., Saparov, K.T., \& Wendt, J.A. (2019). Development of scientific tourism at Baikonur Cosmodrome Kazakhstan. GeoJournal of Tourism and Geosites, 24(1), 267-279. https://doi.org/10.30892/gtg.24121-358

Koshim, A., Karatayev, M., Clarke, M.L., \& Nock, W. (2018). Spatial assessment of the distribution and potential of bioenergy resources in Kazakhstan. Advances in Geosciences, 45, 217-225. https://doi.org/10.5194/adgeo-45-217-2018

Lepoutre, J., \& Heene, A. (2006). Investigating the impact of firm size on small business social responsibility: A critical review. Journal of Business Ethics, 67(3), 257-273. https://doi.org/10.1007/s10551-006-9183-5

Lerner, M., \& Haber, S. (2001). Performance factors of small tourism ventures: The interface of tourism, entrepreneurship and the environment. Journal of business venturing, 16(1), 77-100. https://doi.org/10.1016/S0883-9026(99)00038-5

Lonial, S.C., \& Carter, R.E. (2015). The impact of organizational orientations on medium and small firm performance: A resource-based perspective. Journal of Small Business Management, 53(1), 94-113. https://doi.org/10.1111/jsbm.12054

Maksimov, V., Wang, S.L., \& Luo, Y. (2017). Reducing poverty in the least developed countries: The role of small and medium enterprises. Journal of World Business, 52(2), 244-257. https://doi.org/10.1016/j.jwb.2016.12.007

Malesios, C., Skouloudis, A., Dey, P.K., Abdelaziz, F.B., Kantartzis, A., \& Evangelinos, K. (2018). Impact of small-and medium-sized enterprises sustainability practices and performance on economic growth from a managerial perspective: Modeling considerations and empirical analysis results. Business Strategy and the Environment, 27(7), 960-972. https://doi.org/10.1002/bse.2045

Memili, E., Fang, H., Chrisman, J.J., \& De Massis, A. (2015). The impact of small-and medium-sized family firms on economic growth. Small Business Economics, 45(4), 771-785. https://doi.org/10.1007/s11187-015-9670-0

Menard, S. (2000). Coefficients of determination for multiple logistic regression analysis. The American Statistician, 54(1), 17-24. https://doi.org/10.1080/00031305.2000.10474502

Movkebayeva, G., Aktymbayeva, A., Tyurina, Y., Baikadamov, N., Beketova, K., Troyanskaya, M., \& Imangaliyeva, A. (2020). Energy Security and Sustainability in Eurasian Economic Union in the Terms of Economic Growth: The Case of Kazakhstan's Energy Sector up to 2040 Perspectives. International Journal of Energy Economics and Policy, 10(2), 497-503. https://doi.org/10.32479/ijeep.9073

Mueller, P. (2007). Exploiting entrepreneurial opportunities: The impact of entrepreneurship on growth. Small Business Economics, 28(4), 355-362. https://doi.org/10.1007/s11187-006-9035-9

Nga, J.K.H., \& Shamuganathan, G. (2010). The influence of personality traits and demographic factors on social entrepreneurship start up intentions. Journal of business ethics, 95(2), 259-282. https://doi.org/10.1007/s10551-009-0358-8

Noguera, M., Alvarez, C., \& Urbano, D. (2013). Socio-cultural factors and female entrepreneurship. International Entrepreneurship and Management Journal, 9(2), 183-197. https://doi.org/10.1007/s11365-013-0251-x

Oosterbeek, H., Van Praag, M., \& Ijsselstein, A. (2010). The impact of entrepreneurship education on entrepreneurship skills and motivation. European Economic Review, 54(3), 442-454. https://doi.org/10.1016/j.euroecorev.2009.08.002

Peng, C.Y.J., Lee, K.L., \& Ingersoll, G.M. (2002). An introduction to logistic regression analysis and reporting. The journal of educational research, 96(1), 314. https://doi.org/10.1080/00220670209598786

Rocha, H.O. (2004). Entrepreneurship and development: The role of clusters. Small Business Economics, 23(5), 363-400. https://doi.org/10.1007/s11187-004-3991-8

Saiymova, M., Seisinbinova, A., Dauletova, R., Iskakov, S., Suleimenova, B., Bekbulatova, R., \& Kabdullina, G. (2018). Complex Innovation Policy in Kazakhstan with the New Legal Regulations: Key Issues and Challenges. Journal of Advanced Research in Law and Economics, 9 (8), $2790-2797$. https://doi.org/10.14505/jarle.v9.8(38).28.

Saiymova, M., Shakharova, A., Rakaeva, A., Serikova, M., Tasmaganbetov, A., Tyurina, Y., \& Bimagambetova, Z. (2020). Energy Security, Economics and Environment in the Eurasian Economic Union: Current and Future Scenarios. International Journal of Energy Economics and Policy, 10(4), 293-299. https://doi.org/10.32479/ijeep.9127

Singh, N.P., Molokov, D., Lechshak, S., \& Kuspanov, A. (2012). Information systems in small and medium enterprises in Republic of Kazakhstan. African Journal of Business Management, 6(23), 7042. https://doi.org/10.5897/ajbm10.137

Taiwo, M.A., Ayodeji, A.M., \& Yusuf, B.A. (2012). Impact of small and medium enterprises on economic growth and development. American Journal of Business and Management, 1(1), 18-22. https://doi.org/10.11634/21679606170644

Tonidandel, S., \& LeBreton, J.M. (2011). Relative importance analysis: A useful supplement to regression analysis. Journal of Business and Psychology, 26(1), 1-9. https://doi.org/10.1007/s10869-010-9204-3

*** National Statistics Agency (NSA). Socio-Economic outlook for 1995-2019. Nursultan, Kazakhstan. Available at: stat.gov.kz. 